\title{
First detection and molecular characterization of hepatitis E virus in water from wastewater treatment plants in Portugal
}

\author{
Ana Matos ${ }^{1, A-B, F}$, João R Mesquita ${ }^{2, C-F}$, Daniel Gonçalves ${ }^{3, B, F}$, Joana Abreu-Silva ${ }^{4, B, F}$, \\ Cristina Luxo ${ }^{3, \mathrm{~A}, \mathrm{E}-\mathrm{F}}$, Maria SJ Nascimento ${ }^{4, C-F}$ \\ ${ }^{1}$ Centro de Investigação em Engenharia dos Processos Químicos e dos Produtos da Floresta (CIEPQF), Faculdade de \\ Farmácia da Universidade de Coimbra, Portugal \\ ${ }^{2}$ Agrarian Superior School, Polytechnic Institute of Viseu, Portugal \\ ${ }^{3}$ Laboratório de Virologia, Grupo das Biociências Clínicas e Aplicadas, Faculdade de Farmácia da Universidade de \\ Coimbra, Portugal \\ ${ }^{4}$ Laboratório de Microbiologia, Departamento de Ciências Biológicas, Faculdade de Farmácia da Universidade do Porto, \\ Porto, Portugal \\ A - Research concept and design, B - Collection and/or assembly of data, C - Data analysis and interpretation, \\ $D$ - Writing the article, $E$ - Critical revision of the article, $F$ - Final approval of article
}

\begin{abstract}
Matos A, Mesquita JR, Gonçalves D, Abreu-Silva J, Luxo C, Nascimento MSJ. First detection and molecular characterization of hepatitis E virus
\end{abstract} in water from wastewater treatment plants in Portugal. Ann Agric Environ Med. 2018; 25(2): 364-367. doi: 10.26444/aaem/90497

\begin{abstract}
Hepatitis E virus (HEV) genotype 3 is widespread in industrialized countries and widely recognized as a serious public health issue. HEV genotype 3 is excreted in both human and animal stools, having the potential to be introduced in aquatic environments through wastewater discharge. For this reason, waterborne transmission of the HEV genotype 3 is drawing increasing attention from the scientific community. Although studies in Portugal have shown that HEV circulates in both humans and swine, no study has yet focused on the presence of HEV in wastewater. Hence, a total of 60 water samples (influent and effluent) from 15 Wastewater Treatment Plants (WWTP) of different regions of Portugal were tested for the presence of HEV using a broad spectrum real-time RT-PCR with amplification within the ORF2 region of HEV genome. Positive samples were retested by nested RT-PCR with amplification within the ORF1 region, sequenced followed by phylogenetic analysis. HEV sequences were retrieved from two influent samples collected in December 2013 from WWTPs of North and Central of Portugal and classified in subgenotype $3 \mathrm{i}$ and $3 \mathrm{f}$. This is the first study showing the presence of HEV in aquatic environments of Portugal.
\end{abstract}

Key words

wastewater, hepatitis E virus, genotype 3, zoonotic

\section{INTRODUCTION}

Hepatitis E virus (HEV) is a positive sense, single-stranded, non-enveloped hepatotropic virus belonging to the Orthohepevirus genus, Hepeviridae family [1]. Genotype 3 $\mathrm{HEV}$ is widespread in industrialized countries and infection in humans is mostly the result of foodborne zoonotic transmission from swine, considered the most important animal reservoir for human disease $[2,3]$. Since HEV is excreted in stools, it has the potential to be introduced in aquatic environments through urban and agriculture runoff, sewage outfall and vessel wastewater discharge. The involvement of environmental transmission in HEV genotype 3 infection is uncertain, but the hypothesis of waterborne transmission has been drawing increasing attention from the scientific community [4]. Further concerns are apparent since, unlike bacteria, viruses are not so efficiently eliminated by wastewater treatment plants and, as a consequence, they can be released in aquatic environments at levels that can have significance for public health $[5,6,7]$. Several countries worldwide have reported the detection

Address for correspondence: João RMesquita, Agrarian Superior School, Polytechnic Institute of Viseu, Quinta da Alagoa, Estrada de Nelas, 3500-606 Viseu, Portugal e-mail: jmesquita@esav.ipv.pt

Received: 22.02.2018; accepted: 25.04.2018; first published: 17.05.2018 of HEV in wastewater samples $[8,9,10]$. Since Portugal is considered an endemic country for $\operatorname{HEV}[11,12]$ and past studies have confirmed the presence of HEV in swine $[2,13]$, it is expected that HEV could be released into the aquatic environment. To the best of our knowledge, no study on the detection of $\mathrm{HEV}$ or any viral enteric pathogen in wastewater has ever been carried out in Portugal. This study presents data from the first detection and molecular characterization of HEV isolates retrieved from Wastewater Treatment Plants (WWTP) in Portugal.

\section{MATERIALS AND METHOD}

A total of 60 influent and effluent wastewater samples from 15 WWTPs located in 5 Portuguese regions - North, Centre, Lisboa and Vale do Tejo, Alentejo and Algarve were studied. From each WWTP, time proportional 24-h composite influent $(\mathrm{N}=1)$ and effluent $(\mathrm{N}=1)$ samples $(250 \mathrm{ml})$ were collected in September and in December 2013, in highdensity polyethylene containers. Samples were transported refrigerated $\left( \pm 4^{\circ} \mathrm{C}\right)$ to the laboratory and kept frozen $\left(-20^{\circ} \mathrm{C}\right)$ until analysis. Viral concentration was performed according to a previously described method [14] with minor modifications. 
Briefly, suspended materials of each wastewater sample were removed by 3 successive filtrations, through a glass microfiber filter, a $0.45 \mu \mathrm{m}$ and a $0.2 \mu \mathrm{m}$ polyamide membrane filters, respectively. 75 millilitres of filtrate were then ultracentrifuged at $15,2743 \mathrm{~g}$ (Ultracentrifuge L-80, Beckman) for $90 \mathrm{~min}$ at $18^{\circ} \mathrm{C}$. The resulting pellet was resuspended in $500 \mu \mathrm{L}$ of supernatant. An equal volume of chloroform was then added. After homogenization and centrifugation at $405 \mathrm{~g}$ (Sigma 3-15) for $10 \mathrm{~min}$, the aqueous phase was collected and stored at $-20^{\circ} \mathrm{C}$ until nucleic acid extraction. Nucleic acid was extracted from $140 \mu \mathrm{L}$ of this phase using the QIAmp ${ }^{\circledast}$ Viral RNA Mini Kit (QIAGEN, Hilden, Germany), according to the manufacturer's instructions. Each extraction protocol was performed along with a negative and a positive control, consisting of sterile water and HEV RNA added to a known negative sample, respectively. For HEV detection, a broad real time RT-PCR (RT-qPCR) TaqMan probe assay targeting the open reading frame (ORF) 2 region of the HEV was performed [15]. Briefly, to $12.5 \mu \mathrm{l}$ of reaction mix (SuperScript ${ }^{\oplus}$ III Platinum OneStep RT-qPCR Kit, Invitrogen), were added $0.8 \mu \mathrm{l}$ SuperScript TM III RT/Platinum Taq enzyme, 10 pmol of each primer, 3 pmol of probe and $5 \mu \mathrm{l}$ of extracted nucleic acid, made up to $25 \mu \mathrm{l}$ with RNAse-free water. Thermal profile consisted of incubation at $50^{\circ} \mathrm{C}$ for $30 \mathrm{~min}$, denaturation at $95^{\circ} \mathrm{C}$ for 2 min and then 45 cycles of amplification with denaturation at $95^{\circ} \mathrm{C}$ for $15 \mathrm{~s}$, and annealing/extension at $60^{\circ} \mathrm{C}$ for 1 min acquiring on the FAM and ROX channels. Real-time measurements were taken at each cycle.

Samples positive by RT-qPCR were submitted to a nested broad-spectrum RT-PCR with amplification within the ORF1 region of HEV genome [16]. In short, the first round of RTPCR was performed using the Qiagen One-Step RT-PCR Kit (QUIAGEN, Hilden, Germany) with primers HEV-cs and HEV-cas that amplify a 472-bp fragment. Thermal profile consisted of $42^{\circ} \mathrm{C}$ for $60 \mathrm{~min}$ and $95^{\circ} \mathrm{C}$ for $15 \mathrm{~min}$, followed by 40 cycles of $94^{\circ} \mathrm{C}$ for $1 \mathrm{~min}, 50^{\circ} \mathrm{C}$ for $1 \mathrm{~min}$ and $74^{\circ} \mathrm{C}$ for 1 min, with a final extension at $72^{\circ} \mathrm{C}$ for $10 \mathrm{~min}$. For the second round PCR, HiFi Hotstart ReadyMix (KAPA Biosystems, MA, USA) was used, and the primers HEV-csn and HEVcasn that amplify a 334-bp fragment, using as template $5 \mu \mathrm{l}$ of the first round products. The thermal profile consisted of $95^{\circ} \mathrm{C}$ for $5 \mathrm{~min}$ and $35 \mathrm{cycles}$ of $94^{\circ} \mathrm{C}$ for $30 \mathrm{sec}, 50^{\circ} \mathrm{C}$ for $30 \mathrm{sec}$ and $72^{\circ} \mathrm{C}$ for $1 \mathrm{~min}$, with a final extension at $72^{\circ} \mathrm{C}$ for $10 \mathrm{~min}$. Each set of amplification reactions in both RTqPCR and conventional RT-PCR included a positive and a negative amplification control. The negative control consisted of sterile water added to the reaction mixture instead of nucleic acid extract. HEV genome containing plasmid was used as positive control for amplification reactions. Amplified products were separated by electrophoresis in a $1.5 \%$ agarose gel and appropriately-sized bands were excised and purified with the GRS PCR \& Gel Band Purification Kit (GRISP, Porto, Portugal), and sequenced in both directions using the BigDye Terminator v1.1 Cycle Sequencing kit (PE Applied Biosystems, CA, USA). Sequence editing and multiple alignments were performed with the BioEdit software package, version 2.1 (Ibis Biosciences, CA, USA). Phylogenetic analysis was performed using MEGA version 6.06 software.

\section{RESULTS AND DISCUSSION}

Only 2 of the 60 tested wastewater samples were positive for HEV RNA by RT-qPCR. They were both influent wastewater samples collected in December, one (sample WW9) retrieved from a WWTP located in the North, and the other (sample WW19) located in the Centre of Portugal (Fig. 1). The WWTP located in the North is designed for 255,557 population equivalents, with a median average load of $15,000 \mathrm{~m}^{3}$ per day. This WWTP treats domestic and industrial wastewaters, operating with tertiary treatments, having its discharge point in the Ave River. The WWTP located in the Centre of Portugal is designed for 213,000 population equivalents, with a median average load of $36,000 \mathrm{~m}^{3}$ per day. This WWTP treats domestic and industrial wastewaters through secondary treatment processes, having discharge points in Mondego River. When these 2 samples were retested by nested RT-PCR with primers targeting the ORF 1 region, amplified products of the expected size (330 nt) were obtained. These 2 amplicons were sequenced and submitted to phylogenetic analysis. The nucleotide sequences determined in the presented study

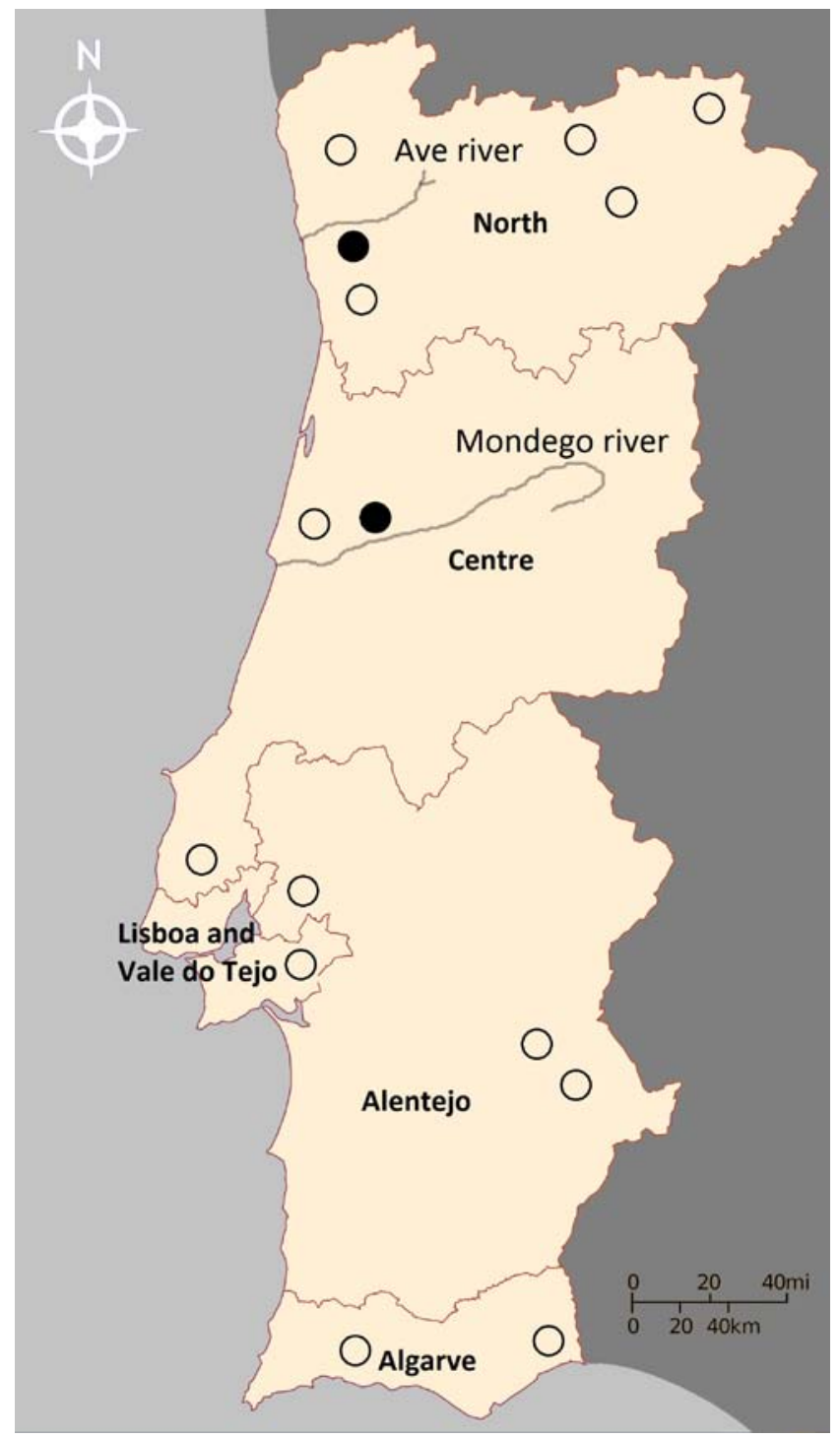

Figure 1. Regions of Portugal showing the location of WWTPs sampled in the study. O - WWTPs where no HEV RNA was detected; $\bullet$ - WWTPs with influents positive for HEV RNA 
have been deposited in the GenBank under Accession Nos.: KX073465 and KX073466. Phylogenetic analysis showed that both isolates belonged to genotype 3 (Fig. 2) but clustering in different subgenotypes, namely subgenotype 3i (WW9) and subgenotype $3 f$ (WW19) and presenting only $79.2 \%$ nucleotide sequence homology. Curiously, the isolate retrieved from the wastewater of the Centre of Portugal (WW19) shared 94.2\% nucleotide sequence homology with the isolate HSJ-GB (GenBank Accession No.: KF564242), retrieved from a patient in North of Portugal in 2012 with an acute case of hepatitis E complicated by Guillain-Barré syndrome [17].

Although no HEV positive samples were detected in the effluent wastewaters of the $2 \mathrm{HEV}$ contaminated influents, this does not necessarily mean that the corresponding effluents were free of HEV. In fact, we did not guard against false-negative results due to PCR inhibitors or low viral concentration and nucleic acid extraction efficiencies, for which it would have been necessary to add internal quality controls to each sample. Nevertheless, the aim of this study

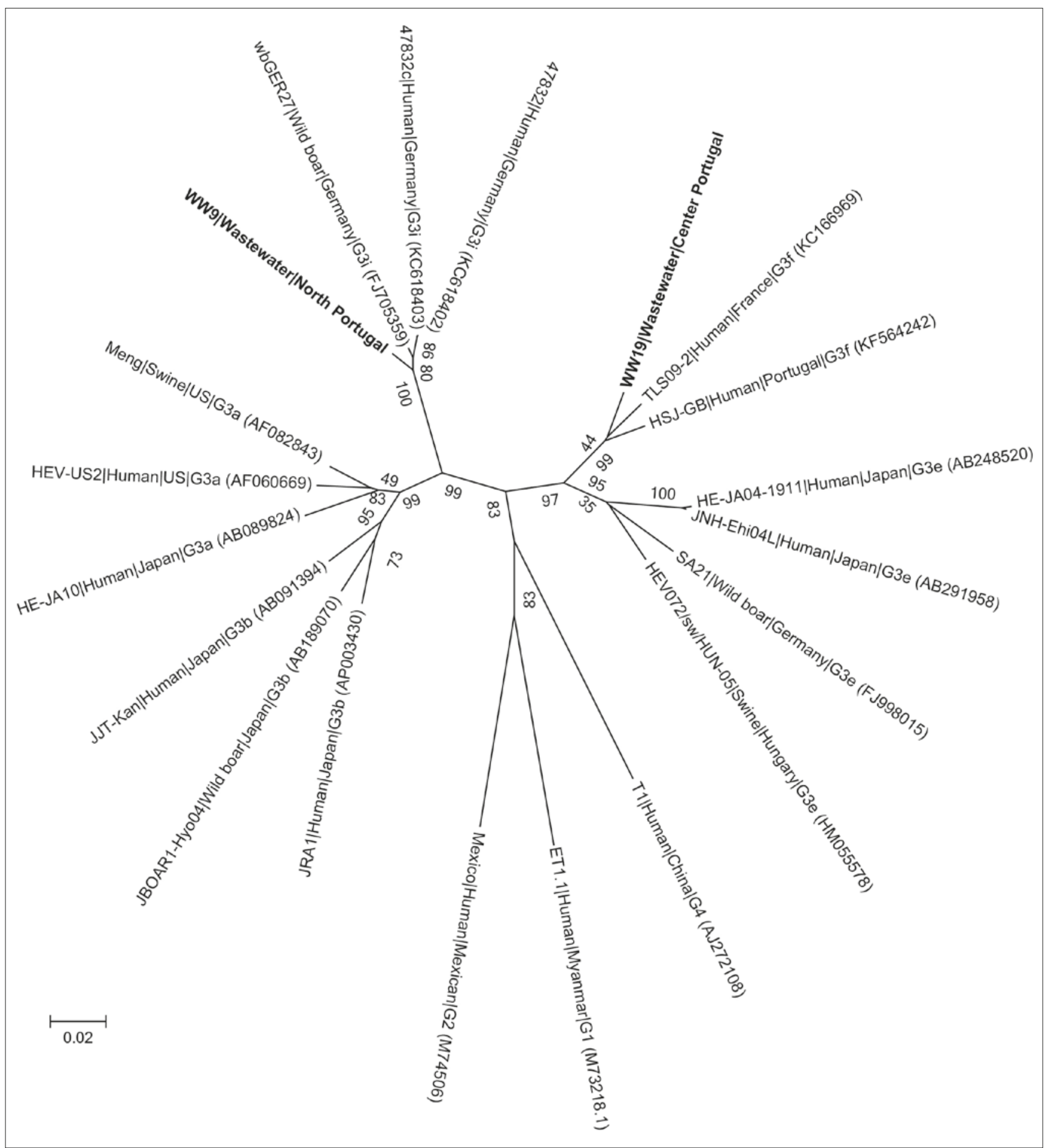

Figure 2. Phylogenetic tree based on nucleotide sequences (324 bp) using Neighbour-Joining algorithm of the HEV isolates (WW9 and WW19; GenBank Accession Nos.: KX073465 and KX073466, respectively) obtained in this study, in relation to sequences representing genotype 3 subgenotypes (3a, $3 \mathrm{~b}, 3 \mathrm{e}, 3 \mathrm{i}$ and $3 \mathrm{f}$ ) and the outgroup isolates (genotype 1, 2 and 4). Evolutionary distances were computed using the Maximum Composite Likelihood method. Bootstrap test (1,000 replicates) are shown next to the branches. Scale bar indicates substitutions per nucleotide position. Sequences are defined in tree as Strain|Host|Origin|Subgenotype (Accession No.). 
was to perform the molecular characterization of $\mathrm{HEV}$ isolates from the environment rather than to evaluate viral occurrence. Molecular diagnostic tools are known to be valuable for environmental surveillance, assisting in the assessment of the epidemiology of the circulating viral community in a given population $[4,18]$. In fact, reports have shown a correlation between viruses detected in wastewater and clinical cases, showing that this type of study is very useful for virus monitoring, and even for outbreak early warning systems $[19,20]$.

\section{CONCLUSIONS}

The presented study described the detection of HEV genotype 3 sequences in wastewater samples of WWTPs in the North and Centre of Portugal, and to the best knowledge of the authors is the first study to investigate the presence of $\mathrm{HEV}$ in aquatic environments of Portugal. Future studies should focus on the potential impact of waterborne HEV on public health.

\section{Acknowledgements}

The authors would like to express their deep gratitude to Angelina Pena and co-researchers from the Faculty of Pharmacy, University of Coimbra, for supplying wastewater samples and sharing the demographical characteristics of WWTPs.

\section{REFERENCES}

1. Smith DB, Simmonds P, \& International Committee on Taxonomy of Viruses Hepeviridae Study Group. Consensus proposals for classification of the family Hepeviridae. J Gen Virol. 2014; 95: 2223 2232 .

2. Berto A, Backer JA, Mesquita JR, Nascimento MS, Banks M, Martelli F, Ostanello F, Angeloni G, Di Bartolo I, Ruggeri FM, Vasickova P, Diez-Valcarce M, Hernandez M, Rodriguez-Lazaro D, van der Poel WH. Prevalence and transmission of hepatitis E virus in domestic swine populations in different European countries. BMC Res Notes. 2012; 25(5): 190.

3. Teixeira J, Mesquita JR, Pereira SS, Oliveira RM, Abreu-Silva J, Rodrigues A, Myrmel M, Stene-Johansen K, Øverbø J, Gonçalves G, Nascimento MS. Prevalence of hepatitis E virus antibodies in workers occupationally exposed to swine in Portugal. Med Microbiol Immunol. 2017; 206(1): 77-81.

4. Van der Poel WH. Food and environmental routes of Hepatitis E virus transmission. Curr Opin Virol. 2014; 4: 91-96.
5. Ouardani I, Manso CF, Aoun M, Romalde JL. Efficiency of hepatitis A virus removal in six sewage treatment plants from central Tunisia. Appl Microbiol Biotechnol. 2015; 99: 10759-69.

6. Prevost B, Lucas FS, Goncalves A, Richard F, Moulin L, Wurtzer S. Large scale survey of enteric viruses in river and waste water underlines the health status of the local population. Environ Int. 2015; 79: 42-50.

7. Mesquita JR, Oliveira D, Rivadulla E, Abreu-Silva J, Varela MF, Romalde JL, Nascimento MS. Hepatitis E virus genotype 3 in mussels (Mytilus galloprovinciallis), Spain. Food Microbiol. 2016; 58: 13-15.

8. Martínez Wassaf MG, Pisano MB, Barril PA, Elbarcha OC, Pinto MA, Mendes de Oliveira J, DiGiusto P, Nates SV, Ré VE. First detection of hepatitis E virus in Central Argentina: environmental and serological survey. J Clin Virol. 2014; 61: 334-9.

9. Li H, Li W, She R, Yu L, Wu Q, Yang J, Hu F, Soomro MH, Shi R, Hao W, Zhao Y, Mao J. Hepatitis E Virus Genotype 4 Sequences Detected in Sewage from Treatment Plants of China. Food Environ Virol. 2017; 9: 230-233

10. Masclaux FG, Hotz P, Friedli D, Savova-Bianchi D, Oppliger A. High occurrence of hepatitis $\mathrm{E}$ virus in samples from wastewater treatment plants in Switzerland and comparison with other enteric viruses. Water Res. 2013; 47: 5101-9.

11. Oliveira R, Mesquita JR, Pereira S, Abreu-Silva J, Teixeira J, Nascimento MSJ. Seroprevalence of Hepatitis E Virus Antibodies in Portuguese Children. Pediatr Infect Dis J. 2017; 36: 623-626.

12. Nascimento MSJ, Pereira SS, Teixeira J, Abreu-Silva J, Oliveira RMS, Myrmel M, Stene-Johansen K, Øverbø J, Gonçalves G, Mesquita JR. A nationwide serosurvey of hepatitis E virus antibodies in the general population of Portugal. Eur J Public Health. 2017. 11. [Epub ahead of print].

13. Mesquita JR, Oliveira RM, Coelho C, Vieira-Pinto M, Nascimento MS. Hepatitis E Virus in Sylvatic and Captive Wild Boar from Portugal. Transbound Emerg Dis. 2016; 63: 574-8.

14. Rafique A, Jiang S. Genetic diversity of human polyomavirus JCPyV in Southern California wastewater. J Water Health. 2008; 6: 533-538.

15. Rolfe KJ, Curran MD, Mangrolia N, Gelson W, Alexander GJ, L'estrange M, Vivek R, Tedder R, Ijaz S. First case of genotype 4 human hepatitis E virus infection acquired in India. J Clin Virol. 2010 May; 48(1): 58-61.

16. Johne R, Plenge-Bönig A, Hess M, Ulrich RG, Reetz J, Schielke A. Detection of a novel hepatitis E-like virus in faeces of wild rats using a nested broad-spectrum RT-PCR. J Gen Virol. 2010 Mar; 91(Pt 3): 750-8.

17. Santos L, Mesquita JR, Rocha Pereira N, Lima-Alves C, Serrão R, Figueiredo P, Reis J, Simões J, Nascimento M, Sarmento A. Acute hepatitis E complicated by Guillain-Barre syndrome in Portugal, December 2012--a case report. Euro Surveill. 2013 Aug 22; 18(34). pii: 20563.

18. Barril PA, Giordano MO, Isa MB, Masachessi G, Ferreyra LJ, Castello AA, Glikmann G, Nates SV. Correlation between rotavirus A genotypes detected in hospitalized children and sewage samples in 2006, Córdoba, Argentina. J Med Virol. 2010 Jul; 82(7): 1277-81.

19. Prado T, Fumian TM, Miagostovich MP, Gaspar AM. Monitoring the hepatitis A virus in urban wastewater from Rio de Janeiro, Brazil. Trans R Soc Trop Med Hyg. 2012 Feb; 106(2): 104-9.

20. Hellmér M, Paxéus N, Magnius L, Enache L, Arnholm B, Johansson A, Bergström T, Norder H. Detection of pathogenic viruses in sewage provided early warnings of hepatitis A virus and norovirus outbreaks. Appl Environ Microbiol. 2014 Nov; 80(21): 6771-81. 